(дознания, предварительного следствия), а также судебного разбирательства, а затем вынесения приговора. Также присвоение квалификации входит в задачи надзорного и кассационного производства по уголовным делам [4,С.59].

Выводы о наличии в деянии состава преступления, соответствующего установленным уголовно-правовым нормам, отражены в документах следственных органов. В этих документах подробно и точно зафиксированы названия всех статей, подпадающих под состав преступления [3,С.156].

Определение состава преступления и квалификация преступлений - это один из важнейших моментов в работе правоохранительных органов. Сотрудник правоохранительных органов наделяется широчайшими полномочиями в вопросах принятия решения о квалификации преступления. Этот пункт также определяет полную ответственность за решение, принятое сотрудником правоохранительных органов по данному делу.

Проблемы классификации преступлений по составу все еще существуют, несмотря на многочисленные попытки сделать четкую классификацию. Установление конкретных элементов преступления в деянии может быть достигнуто только путем квалификации преступления. Это обоснование с точки зрения закона, согласно которому лицо подлежит уголовной ответственности, применяет принудительные меры, обвиняется, определяет приговор или наказание, исполняется.

К сожалению, квалификация деяния на основе состава преступления может иметь ошибки.

Исходя из вышесказанного можно сделать вывод о том, что квалификационными ошибками являются неправильно установленные отсутствие или наличие признаков преступления, а также соответствие его Уголовному кодексу Российской Федерации. Такие ошибки носят уголовно-правовой характер, в отличие от уголовно-процессуальных. Основными источниками таких ошибок являются недостатки в правоприменении и несовершенство законодательства.

$$
* * *
$$

1. Бриллиантов А. В., Четвертакова Е. Ю. Уголовное право Российской Федерации в схемах. Учебное пособие. - М.: Проспект. -2020. - 624 с.

2. Гриненко, А.В. Уголовный процесс: учебник и практикум / А. В. Гриненко. - Москва: Юрайт, 2017. - 333 c.

3. Джинджолия Р. С., Боровиков В. Б. Российское уголовное право. В 2 частях. Общая часть. Учебно-наглядное пособие (схемы). - М.: Прометей. -2018. -158 с.

4. Капинус О.С. Уголовное право России. Особенная часть в 2 томах. Том 2. Учебник для академического бакалавриата. - М.: Юрайт. -2017. -504 с.

\title{
Клысь Э.Д.
}

Малозначительность правонарушения и критерии его определения

Российский государственный университет правосудия (Россия, Симферополь)

doi: 10.18411/lj-05-2020-205

idsp: ljournal-05-2020-205

\section{Аннотация}

В статье рассматривается категория малозначительности административного правонарушения. Определяются основные критерии, которые свидетельствуют о наличии признаков малозначительности в административном правонарушении и проблемы их определения уполномоченными на то органами.

Ключевые слова: административное право, административное правонарушение, административная ответственность, малозначительность. 
Abstract

The category of insignificance of an administrative offense is available in the article. Defined basic criteria, which are signs of insignificance in an administrative offense, and problems associated with their permission to use.

Keywords: administrative law, administrative offense, administrative responsibility, insignificance.

Действующее административное законодательство включает в себя ряд оценочных понятий, которые до сих пор прямо не раскрываются законодателем. Ст. 2.9 КоАП РФ закрепляет, что уполномоченные органы вправе освободить лицо от административной ответственности, если примут решение о малозначительности [1]. Однако в первую очередь требуется обратиться к тому, что собой вообще представляет малозначительность.

В 2004 году Пленум ВАС РФ Постановлением от 02.06.2004 №10 дал разъяснения, касающиеся определения малозначительности [2]. В нем указано, что личность, имущественное положение привлекаемого к ответственности лица, добровольное устранение правонарушения и возмещение причинённого ущерба являются обстоятельствами, которые учитываются при назначении административного наказания.

В скором времени свою позицию высказал и Верховный Суд Российской Федерации. В абз. 3 п. 21 Постановления Пленума ВС РФ от 24 марта 2005 г. N 5 "О некоторых вопросах, возникающих у судов при применении Кодекса Российской Федерации об административных правонарушениях" он определил свое видение понятия малозначительности.

Так, по его мнению, малозначительным административным правонарушением является действие или бездействие, хотя формально и содержащее признаки состава административного правонарушения, но с учетом характера совершенного правонарушения и роли правонарушителя, размера вреда и тяжести наступивших последствий не представляющее существенного нарушения охраняемых общественных правоотношений[3].

Исходя из данного понятия, мы понимаем то, что, малозначительность правонарушения отражается в отсутствии угрозы общественным отношениям, наименьшая степень общественной вредности.

Институт малозначительности деяния в административном праве характеризуется следующими признаками:

- решение принимается непосредственно тем субъектом, который рассматривает дело об административном правонарушении;

- наличие события административного правонарушения;

- $\quad$ наличие состава административного правонарушения;

- лицо, привлекаемое к административной ответственности, обладает правоспособностью;

- его деянию дается характеристика как малозначительному;

- сопровождается устным замечанием [4, с. 272].

Критерий малозначительности применяется исключительно к конкретному случаю после тщательного изучения всех материалов и обстоятельств дела. Положения КоАПа РФ прямо не закрепляют ограничения применения на какие-либо составы административных правонарушений. Однако, правоприменителю следует учитывать, что некоторые административные правонарушения существенно нарушают общественные отношения и не могут быть признаны малозначительными. Так, например, ст. 12.8 КоАП РФ закрепляет ответственность за управление транспортным средством водителем, находящимся в состоянии опьянения, а также передачу 
управления транспортным средством лицу, находящемуся в состоянии опьянения. Из диспозиции статьи видно, что данное нарушение статьи никак не может характеризоваться отсутствием угрозы обществу.

Не смотря на разъяснения высших судов, на практике остается открытым вопрос о том, какие критерии свидетельствуют о наличии признаков малозначительности правонарушения. В связи с этим разными судами малозначительность административного правонарушения определяется по-разному, что не позволяет говорить о единстве правоприменительной практики при решении этого вопроса [5, c.173].

Так, Красногвардейский районный суд Республики Крым постановлением №555/2018 от 12.02.2018 прекратил производство по делу, освободил лицо, привлекаемое к административной ответственности от административной ответственности объявив ему устное замечание. Как следует из материалов дела, гражданин допустил наезд на столб, после чего оставил место ДТП. Он полностью признал свою вину в оставлении места ДТП, однако пояснил, что уехать с места ДТП ему пришлось, так как у него произошел инсульт. Суд принял во внимание данное обстоятельство и пришел к выводу, что действия гражданина не представили существенной угрозы охраняемым общественным отношениям и признал действия гражданина малозначительными [6].

В данном случае мы видим, что суд неправильно применил малозначительность. Инсульт произошел после ДТП, был вызван самим ДТП. Если инсульт лица подтверждён документами из медицинского учреждения, то можно считать, что лицо действовало в условиях крайней необходимости, что исключает производство по делу об оставлении места дорожно-транспортного происшествия.

Ялтинский городской суд Республики Крым постановлением от 20.06.2019 освободил от административной ответственности ФГБОУ МДЦ «Артек» и ограничился устным замечанием по делу №5-229/2019. ФГБОУ МДЦ «Артек» совершило административное правонарушение, предусмотренное ч.3 ст.18.15 КоАП РФ, то есть нарушило установленную форму уведомления территориального органа федерального органа исполнительной власти, осуществляющего федеральный государственный контроль (надзор) в сфере миграции, о заключении или прекращении (расторжении) трудового договора или гражданско-правового договора на выполнение работ (оказание услуг) с иностранным гражданином в срок, не превышающий трех рабочих дней с даты заключения, прекращения (расторжения) договора. В данном случае нарушение формы уведомления выразилось в отсутствии подписи должностного лица. При вынесении решения суд учел основные виды деятельности учреждения, факт того, что ранее лицо не было привлечено к административной ответственности, а самое главное то, что в данном случае назначение административного наказания в виде штрафа от четырехсот тысяч до восьмисот тысяч рублей либо административное приостановление деятельности на срок от четырнадцати до девяноста суток носит карательный характер и несоразмерно тяжести совершенного правонарушения. На основании этих фактов суд принял решение о малозначительности правонарушения [7].

Однако в ином случае суд отказал в применении малозначительности и назначил административное наказание в виде административного штрафа ниже минимального размера. Киевским районным судом г. Симферополя Республики Крым было рассмотрено дело № 5-431/2019 в отношении ООО «Миллениум голд». Уведомление о заключении трудового договора с гражданином Таджикистана ООО «Миллениум голд» направило в территориальный орган федерального органа исполнительной власти в сфере миграции, допустив неправильное указание реквизитов документа удостоверяющего право на выполнение трудовой деятельности (патента) [8].

Анализируя судебную практику, мы видим, что правоприменитель самостоятельно выделяет критерии малозначительности. Однако ученые-юристы всё- 
таки закрепляют основные характеристики, по которым становится понятно, что совершенное правонарушение можно признать малозначительным.

Ильясова К.А. выделяет два критерия малозначительности. Основной критерий будет различаться, исходя из состава административного правонарушения. При материальном составе ключевым для определения будет минимальный размер причинённого ущерба, когда при формальном составе важна наименьшая вероятность наступления вредных последствий. Второй - дополнительный критерий раскрывает роль правонарушителя в совершенном административном правонарушении [9, с. 370].

Шерстобоев О.Н. отмечает, что малозначительность тесно связана с конструкцией состава правонарушения. При чём, оценка причинённого вреда показывает на то, что основное значение для квалификации правонарушения, как малозначительного, имеют признаки объективной стороны правонарушения [10, с. 57].

Степанов В.В. считает, что при применении категории малозначительности в первую очередь необходимо установить обстоятельства, которые характеризуют личность правонарушителя. При этом, применении малозначительности ограничить только для тех случаев, где санкцией предусматривается предупреждение [11, с. 136].

Исходя их вышеизложенного, можно выделить основные критерии признания малозначительности правонарушения. Основной критерий включает в себя малый размер причинённого ущерба и практически отсутствие негативных последствий. Факультативным критерием можно признать неосторожность совершенного правонарушения, признаки поведения правонарушителя. Поведение правонарушителя должно исключать явное целенаправленное пренебрежение к охраняемым общественным отношениям [12, с. 72].

На данный момент Правительством РФ представлен для обсуждения новый законопроект КоАПа РФ. В связи с множеством вносимых изменений в статьи, на сегодняшний день представляется необходимым кодифицировать совершенно новый акт. Новая концепция предусматривает ясность закона не только для специалистов, но и для обычных граждан.

Новый проект закона более детально регламентирует многие аспекты административных правонарушений, в том числе включая процессуальные моменты, касающиеся производства по делам об административных правонарушениях; вводятся новые понятия. Однако ясность в категорию малозначительности так и не вносится.

Теперь, дается более широкое понятие малозначительности, как основания освобождения от административной ответственности. Так, согласно ст.2.3 проекта нового КоАПа малозначительным административным правонарушением может быть признано действие или бездействие, хотя формально и содержащее признаки состава административного правонарушения, но с учетом характера совершенного правонарушения и роли правонарушителя, размера вреда и тяжести наступивших последствий не представляющее существенного нарушения охраняемых общественных правоотношений. При этом административное правонарушение, считающееся грубым, не может быть признано малозначительным.

Таким образом, мы делаем вывод, что в действующем административном законодательстве природа малозначительности административного правонарушения не урегулирована в должной мере. Правоприменитель достаточно часто допускает ошибки при квалификации административного правонарушения как малозначительного. Малозначительность должна определяться отсутствием угрозы общественным отношениям, а не иными обстоятельствами, закрепленными административным законодательством, которые исключают административную ответственность. Новый законопроект КоАПа РФ должен отразить в своих статьях не только определение понятия малозначительности, но также и критерии определения. В частности, необходимо регламентировать порядок применения данной категории судами и иными 
уполномоченными органами в целях дальнейшего предотвращения ошибок при вынесении решений при рассмотрении дел об административных правонарушениях.

$$
* * *
$$

1. Кодекс Российской Федерации об административных правонарушениях от 30.12.2001 N 195-Ф3 (ред. от 18.03.2020) // "Собрание законодательства РФ", 07.01.2002, N 1 (ч. 1).

2. Постановление Пленума ВАС РФ от 02.06.2004 N 10 (ред. от 21.12.2017) "О некоторых вопросах, возникших в судебной практике при рассмотрении дел об административных правонарушениях" // Вестник ВАС РФ. - 2004. - № 8 .

3. Постановление Пленума ВС РФ от 24 марта 2005 г. N 5 "О некоторых вопросах, возникающих у судов при применении Кодекса Российской Федерации об административных правонарушениях" // Бюллетень Верховного Суда РФ. — 2005. — № 6.

4. Евсикова Е.В., Нозрина Л.В. Понятие малозначительности административного правонарушения и правоприменение норм о малозначительности // Сборник выступлений по итогам проведения Первого Севастопольского юридического форума, прошедшего 27-28 сентября 2018 года на базе Юридического института Севастопольского государственного университета / отв. ред. С.А. Васильева. - М.: Центркаталог, 2019. с. 270-273.

5. Керамова С.Н. Малозначительность административного правонарушения как основание освобождения от административной ответственности. Проблемы правового регулирования // Государственная служба и кадры. 2019. №2. с. 172-174.

6. Постановление Красногвардейского районного суда Республики Крым № 5-55/2018 от 12 февраля 2018 г. по делу № 5-55/2018. // Архив Красногвардейского районного суда Республики Крым [Электронный $\quad$ pecypc] 근 krm.sudrf.ru/modules.php?name=sud_delo\&srv_num $=1 \&$ name_op $=$ doc \&number $=7274058 \& d e l o \_i d=15$ $00001 \&$ new $=0 \&$ text_number $=1$ (дата обращения 10.04.2020)

7. Постановление Ялтинского городского суда Республики Крым № 5-229/2019 от 20 июня 2019 г. по делу № 5-229/2019.// Архив Ялтинского городского суда Республики Крым [Электронный ресурс] URL:

https://yalta--

krm.sudrf.ru/modules.php?name=sud_delo\&srv_num $=1 \&$ name_op $=$ doc $\&$ number $=750251 \&$ delo_id $=150$ $0001 \&$ new $=0 \&$ text_number $=1$ (дата обращения 10.04.2020)

8. Постановление Киевского районного суда г. Симферополя от 09.07.2019 по делу № 5-431/2019. // Архив Киевского районного суда г. Симферополя Республики Крым [Электронный ресурс] - URL: http://kiev-simph--

krm.sudrf.ru/modules.php?name=sud_delo\&srv_num $=1 \&$ name_op=doc $\&$ number $=8229638 \& d e l o \_i d=15$ 00001\&new=\&text_number $=1$ (дата обращения 10.04.2020)

9. Ильясова К. А. Малозначительность правонарушения и его критерии // Аллея науки. 2017. Т. 2. № 16. c. 368-371.

10. Шерстобоев О.Н. К вопросу о малозначительности административных правонарушений: некоторые проблемы теории и практики // Российская юстиция №10. 2008. с. 57-60.

11. Степанов В.В. Малозначительность правонарушения в российском праве: Дисс. ... канд. юрид. наук. [Место защиты: Ин-т законодательства и сравнит. правоведения при Правительстве РФ]. Москва, 2009. 197 с.

12. Пирогов В.Ю. Критерии признания административного правонарушения малозначительным. // Вестник ТюмГУ. Право (№3). 2013. с. 67-74.

\footnotetext{
Ковтун Е.А. ${ }^{1}$, Удалов Д.Э. ${ }^{2}$ Нормативные основы правового воспитания молодежи ${ }^{1}$ ФГАОУ ВО «Национальный исследовательский университет «Высшая школа экономики»

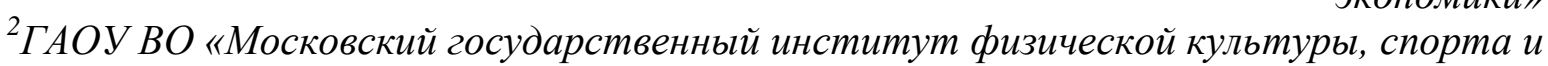
туризма имени Ю.А. Сенкевича» (Россия, Москва)

doi: $10.18411 / \mathrm{j}-05-2020-206$

idsp: ljournal-05-2020-206

\section{Аннотация}

В статье рассматриваются вопросы правового обеспечения деятельности, направленной на формирование правовой культуры, в рамках правового воспитания
} 